\title{
EFFICACY OF BASALT AND GRANITE AS COARSE AGGREGATE IN CONCRETE MIXTURE
}

\author{
Ubi S.E ${ }^{1}{ }^{凶}$, Nkra P.O ${ }^{2}$, Agbor R.B ${ }^{3}$, Ewa D.E ${ }^{1}$, Nuchal M. ${ }^{1}$ \\ ${ }^{1}$ Department of Civil Engineering Cross River University of Technology (CRUTECH), Calabar, \\ Nigeria \\ 2 Department of Works, University of Calabar, Calabar, Nigeria \\ ${ }^{3}$ Environmental Biotechnology unit, Department of Genetics and Biotechnology, University of \\ Calabar, Calabar, Nigeria
}

DOI: https://doi.org/10.29121/ijetmr.v7.i9.2020.769

Article Citation: Ubi S.E, Nkra P.O, Agbor R.B, Ewa D.E, and Nuchal M.. (2020). EFFICACY OF BASALT AND GRANITE AS COARSE AGGREGATE IN CONCRETE MIXTURE.

International Journal of Engineering Technologies and Management

Research, 7(9), 1-9.

https://doi.org/10.29121/ijetmr.v7 .i9.2020.769

Published Date: 08 September 2020

\section{Keywords:}

Granite

Flexural Strength

Basalt

Coarse Aggregate

Compressive Strength

\section{ABSTRACT}

This present research was on the comparison of the efficacious use of basalt and granite as coarse aggregates in concrete work. In order to obtain the basis for comparison, physical and structural tests were conducted on the different materials of the concrete and the concrete samples respectively. Physical test results revealed that basalt have a specific gravity of 2.8 and 2.5, while granite have a specific gravity of 2.9 and 2.6. In density, basalt have a density of $1554.55 \mathrm{~kg} / \mathrm{m} 3$ while granite had a density of $1463.64 \mathrm{~kg} / \mathrm{m} 3$. Aggregate impact test conducted on both aggregates revealed a percentage of $11.05 \%$ for basalt and $12.63 \%$ for granite. The following structural tests were carried out: compressive strength tests, flexural and tensile strength test and the comparative results are as follows. Compressive strength for basalt $36.39 \mathrm{~N} / \mathrm{mm} 2$ while $37.16 \mathrm{~N} / \mathrm{mm} 2$ for granite. $24.81 \mathrm{~N} / \mathrm{mm} 2$ tensile strength for basalt while $12.57 \mathrm{~N} / \mathrm{mm} 2$ for granite, $31.83 \mathrm{~N} / \mathrm{mm} 2$ flexural strength for basalt while $27.97 \mathrm{~N} / \mathrm{mm} 2$ for granite. From the above results, it can be deduced that basalt has higher strength properties than granite. Therefore, more suitable for coarse aggregate in achieving higher strength with some quantity of other composition of the concrete mix when compared to granite.

\section{INTRODUCTION}

Technological advancement is one of the ways of achieving sustainable development globally. The discovery of concrete technology has brought different innovative ideas into it usage. The process of using appropriate ingredient of concrete and estimating relative quantity in other to produce the desired concrete that could stand the test of time in terms of material strength, durability and workability is termed concrete mix design Sobera and Tose (2003). Concrete which is made of cement, fine aggregates (sand) and coarse aggregates is mixed with water, harden with time, served as construction material in engineering sites. Concrete technology deals with the application of concrete at a particular proportion. However, in our contemporary society and due to civilization, many persons have deviated from thatched buildings into the constructive use of concrete materials in designing of houses, bridges, and erosion ways. Construction of buildings involves the usage of concrete in the foundations, columns, beams, slabs and other load carrying areas. Basalt are igneous rock that possess low silica content. They are dark and has a rich source of iron and magnesium. Some basalts appears glassy while others are very fine-grain. Basalt are classified on the

(C) 2020 The Author(s). This is an open access article distributed under the terms of the Creative Commons Attribution License, which permits unrestricted use, distribution, and reproduction in any medium, provided the original author and source are credited. 
basis of chemical and petrographic in two main categories, the tholeiitic and akali basalt. Kasim et al. (2017) evaluated the aggregates properties on the mechanical and absorption characteristics of geopolymer mortars. Three different types of aggregates consisting of river sand, crushed limestone and combined sand-limestone were used in geopolymer mortar. The findings revealed that the crushed limestone produces the highest compressive and splitting tensile strength while the combined sand-limestone shows the lowest water absorption and sorptivity capacity. Krzysztof et al. (2018) examined the effect of the morphology of coarse aggregate on the properties of selfcompacting high-performance fibre-reinforced concrete. It was reported that the morphology of the coarse aggregate had an impact on the rheological properties of the fresh concrete mixture. Mehdi et al. (2018) reported on the optimum oil palm shell content as coarse aggregate in concrete based on mechanical and durability properties. The findings revealed that oil palm shell content should not exceed $60 \%$ of the total volume of coarse aggregate. Dobiszewska et al. (2019) evaluated the effect of basalt powder addition on properties of mortar. The result revealed that the addition of the basalt powder in place of cement decreases the compressive strength. The flexural strength of the mortar was improved at specific instances. Kumar et al. (2015) investigated the use of granite waste as partial substitute to cement in concrete. The granite slurry was used as partial substitute in proportions ranging from $5 \%$ to $20 \%$ by weight of cement in concrete. The comprehensive strength, tensile strength and flextural strength were tested. The findings shows that locally available granite slurry is a good partial substitute to concrete.

\section{MATERIALS AND METHODS}

In more than two decades, lots of materials have been offered in full range for testing to suit the requirements of local, national and international civil engineering contractors, consultants as well as manufacturers, the resource industry and government agencies.

\subsection{AGGREGATE CRUSHING TEST PROCEDURE}

Specimen of aggregate in standard mould were subjected to a compression test under standard load conditions. The dry aggregate were made to pass through $12.5 \mathrm{~mm}$ sieves, retained and sieved in a $10 \mathrm{~mm}$ sieves, this was filled in a cylindrical measure of $11.5 \mathrm{~mm}$ diameter with a $18 \mathrm{~cm}$ height in three layers. Each layer is tempered 25 times with a standard tampering rod. The test sample was weighed and placed in the test cylinder in three layers each layer was being tampered again.

\subsection{SPECIFIC GRAVITY AND WATER ABSORPTION, SIEVE ANALYSIS AND SPLIT TENSILE STRENGTH}

The Aggregate impact test, Specific gravity and water absorption test, sieve analysis test and splitting analysis were performed using standard laboratory procedures as adopted by Ramakanta (2012); BS: 1881: Part 118: 1983; IS: Part 1-2 (2016) respectively.

\subsection{EXPERIMENTAL METHOD}

Different experimental method were adopted to test the components in order to determined physical properties of aggregate of basalt, physical properties of concrete and the density of concrete as shown in Table 1-3 and figure 5 respectively.

\subsection{PHYSICAL PROPERTIES OF AGGREGATE}

The physical properties of aggregate of basalt showing the specific gravity and particle size distribution is presented in Table 1 \& 2 .

Table 1: Specific Gravity

\begin{tabular}{|c|c|c|c|}
\hline Material & River Fine & Coarse Aggregate (Basalt) & Coarse Aggregate (Granite) \\
\hline Specific Gravity, (Gs) & 2.75 & 2.8 & 2.9 \\
\hline
\end{tabular}

From the given Table, basalt has shown that it has more strength than granite and is a better coarse aggregate material. 
Efficacy of Basalt and Granite as Coarse Aggregate in Concrete Mixture

Table 2: Particle size distribution

\begin{tabular}{|c|c|c|c|c|c|c|}
\hline Sieves & $\begin{array}{c}\text { Weight } \\
\text { retained (g) }\end{array}$ & $\begin{array}{c}\text { Cumulative } \\
\text { weight retained }\end{array}$ & $\begin{array}{l}\text { Percentage } \\
\text { retained }\end{array}$ & $\begin{array}{l}\text { Percentage } \\
\text { cumulative }\end{array}$ & $\begin{array}{l}\text { Percentage } \\
\text { passing }\end{array}$ & Specification \\
\hline \multicolumn{7}{|l|}{$20 \mathrm{~mm}$} \\
\hline \multicolumn{7}{|l|}{$14 \mathrm{~mm}$} \\
\hline \multicolumn{7}{|l|}{$10 \mathrm{~mm}$} \\
\hline \multicolumn{7}{|l|}{$6 \mathrm{~mm}$} \\
\hline \multicolumn{7}{|l|}{$5 \mathrm{~mm}$} \\
\hline $4.75 \mathrm{~mm}$ & 38 & 38 & 0.38 & 3.8 & 96.2-- & \\
\hline $3.35 \mathrm{~mm}$ & 34 & 72 & 0.72 & 7.2 & 92.8 & \\
\hline $2.36 \mathrm{~mm}$ & 38 & 110 & 1.1 & 11 & 89 & \\
\hline $1.18 \mathrm{~mm}$ & 178 & 288 & 2.88 & 28.8 & 71.2 & \\
\hline 600mic & 383 & 671 & 6.71 & 67.1 & 32.9 & \\
\hline $425 \mathrm{mic}$ & 19 & 690 & 6.9 & 69 & 31 & \\
\hline 300mic & 217 & 907 & 9.07 & 90.7 & 9.3 & \\
\hline $212 \mathrm{mic}$ & 56 & 963 & 9.63 & 96.3 & 3.7 & \\
\hline $150 \mathrm{mic}$ & 14 & 977 & 9.77 & 97.7 & 2.3 & \\
\hline 75/63mic & 7 & 984 & 9.84 & 98.4 & 1.6 & \\
\hline passing 63mic & 3 & 987 & 9.87 & 98.7 & 1.3 & \\
\hline Total & $1000 \mathrm{~g}$ & & & & & \\
\hline
\end{tabular}

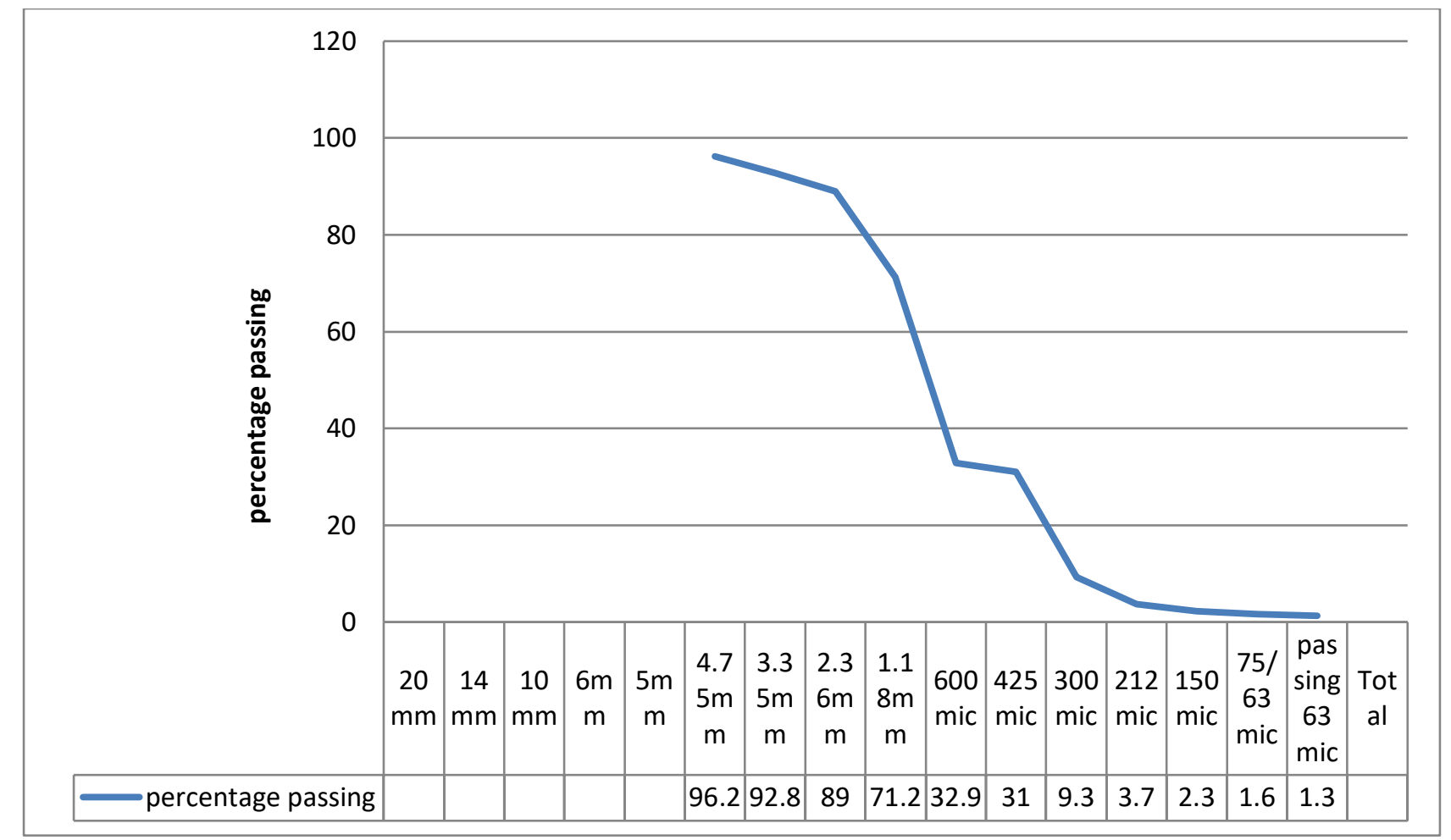

Figure 1: Particle size distribution

Fig. 5: A Graph Showing The Sieve Analysis

\subsection{AGGREGATE IMPACT VALUE}

For basalt, Total weight of aggregate $=w_{1}=362 \mathrm{~g}, w_{2}=0.040 \mathrm{~g}$ hence,

Aggregate impact value $=\frac{w_{2}}{w_{1}} \times 100=\frac{0.040}{362} \times 100=11.05 \%$

For granite $w_{1}=364 \mathrm{~g}, w_{2}=0.046 \mathrm{~g}$,

International Journal of Engineering Technologies and Management Research 
Aggregate impact value $=\frac{w_{2}}{w_{1}} \times 100=\frac{0.046}{364} \times 100=12.63 \%$

Both basalt and granite, from the given results, possess the property of toughness and are strong materials(giving results of between 10-20\%).

\subsection{AGGREGATE CRUSHING VALUE}

For Basalt, Total Weight of Aggregate $=w_{1}=2.585 \mathrm{~kg}, w_{2}=0.759 \mathrm{~kg}$

Hence,

Aggregate Crushing Value $=\frac{w_{2}}{w_{1}} \times 100=\frac{0.759}{2.585} \times 100=29.36 \%$

For Granite, Total Weight of Aggregate $=w_{1}=2.617 \mathrm{~kg}, w_{2}=0.027 \mathrm{~kg}$,

$\frac{w_{2}}{w_{1}} \times 100=\frac{0.027}{2.617} \times 100=1.03 \%$

Given the result shown, basalt possess high resistance during crushing and gradual application of compressive load than granite. Hence, basalt is more preferred than granite.

\subsection{PHYSICAL PROPERTIES OF CONCRETE}

\subsubsection{WORKABILITY OF CONCRETE}

The workability of the fresh concrete was determined by slump test.

The slump test is a measure of the consistency of the concrete as shown in Table 3.

Table 3: Slump Properties

\begin{tabular}{|c|c|c|c|c|}
\hline Maximum size of coarse aggregates & Aggregate type & \multicolumn{3}{|c|}{ Slump(mm) } \\
\cline { 3 - 5 } & & $10-30$ & $30-60$ & $60-180$ \\
\hline \multirow{2}{*}{20} & Crushed & & 180 & 205 \\
\hline & Uncrushed & & 210 & 235 \\
\hline \multirow{2}{*}{40} & Crushed & & 160 & 185 \\
\cline { 2 - 5 } & Uncrushed & & 190 & 215 \\
\hline
\end{tabular}

Slump for granite $=140 \mathrm{~mm}$; Slump for basalt $=90 \mathrm{~mm}$

According to the COREN method of concrete mix design, both aggregates exhibit properties of a high slump.

\subsection{DENSITY OF CONCRETE}

From $\mathrm{V}=\pi \mathrm{r}^{2} \mathrm{~h}$, where $\mathrm{r}$ is the radius $=0.0375 \mathrm{~m}, \mathrm{~h}$ is the height $=0.05 \mathrm{~m}$ therefore; $\mathrm{V}=\pi \times 0.0375^{2} \times 0.05=$ $0.00022 \mathrm{~m}^{3}$

Original mass of cylinder $\mathrm{M}=0.746$, mass of granite $M_{g}=1.068 \mathrm{~kg}$, mass of basalt $M_{b}=1.088 \mathrm{~kg} . M_{g}-M=1.068$ $-0.746=0.322, M_{b}-\mathrm{M}=1.088-0.746=0.342$

Hence, Density of granite $\gamma_{g}=\frac{M}{V}=\frac{0.322}{0.00022}=1463.64 \mathrm{~kg} / \mathrm{m}^{3}$

Density of basalt $\gamma_{b}=\frac{M}{V}=\frac{0.342}{0.00022}=1554.55 \mathrm{~kg} / \mathrm{m}^{3}$

The result showed granite to be less dense than basalt.

\section{RESULTS AND DISCUSSION}

The structural analysis properties of concrete and their responses are presented in Table 4, 5, 6, 7, 8 and 9 respectively. 


\subsection{COMPRESSIVE STRENGTH TEST FOR GRANITE}

The compressive strength test for granite as shown on table 4 show a steady rise in the value of compressive strength as the number of days increased. The maximum strength was obtained after 28days of curing; while Fig. 2, shows a relationship between the increase in compressive strength and the number of days.

Table 4: Compressive strength result for granite

\begin{tabular}{|c|c|c|c|c|c|c|}
\hline \multicolumn{7}{|c|}{ Compressive Strength Tests (Granite) } \\
\hline $\mathrm{S} / \mathrm{N}$ & $\mathrm{M}(\mathrm{Kg})$ & $\begin{array}{l}\text { Casting } \\
\text { Date }\end{array}$ & $\begin{array}{l}\text { Crushing } \\
\text { Date }\end{array}$ & $\begin{array}{l}\text { Crushing Force } \\
\text { (Kn) }\end{array}$ & $\begin{array}{c}\text { Compressive Strength } \\
\left(\mathrm{N} / \mathrm{Mm}^{2}\right)\end{array}$ & $\begin{array}{l}\text { Average Strength } \\
\left(\mathrm{N} / \mathrm{Mm}^{2}\right)\end{array}$ \\
\hline $\mathrm{M}_{1}$ & 2.615 & $28 / 11 / 18$ & $1 / 12 / 2018$ & 206.69 & 20.67 & \multirow[t]{3}{*}{18.62} \\
\hline $\mathrm{M}_{2}$ & 2.539 & $28 / 11 / 18$ & $1 / 12 / 2018$ & 143.41 & 14.34 & \\
\hline $\mathrm{M}_{3}$ & 2.631 & $28 / 11 / 18$ & $1 / 12 / 2018$ & 208.48 & 20.85 & \\
\hline \multicolumn{7}{|c|}{ 7DAYS } \\
\hline $\mathrm{M}_{1}$ & 2.481 & $28 / 11 / 18$ & $6 / 12 / 2018$ & 216.04 & 21.6 & \multirow[t]{3}{*}{22.26} \\
\hline $\mathrm{M}_{2}$ & 2.513 & $28 / 11 / 18$ & $6 / 12 / 2018$ & 228.72 & 22.87 & \\
\hline $\mathrm{M}_{3}$ & 2.491 & $28 / 11 / 18$ & $6 / 12 / 2018$ & 222.95 & 22.3 & \\
\hline \multicolumn{7}{|c|}{14 DAYS } \\
\hline $\mathrm{M}_{1}$ & 2.512 & $28 / 11 / 18$ & $18 / 12 / 18$ & 267.25 & 26.73 & \multirow[t]{3}{*}{24.47} \\
\hline $\mathrm{M}_{2}$ & 2.53 & $28 / 11 / 18$ & $18 / 12 / 18$ & 237.55 & 23.76 & \\
\hline $\mathrm{M}_{3}$ & 2.544 & $28 / 11 / 18$ & $18 / 12 / 18$ & 229.32 & 22.93 & \\
\hline \multicolumn{7}{|c|}{21 DAYS } \\
\hline $\mathrm{M}_{1}$ & 2.57 & $28 / 11 / 18$ & $24 / 12 / 18$ & 244.51 & 24.45 & \multirow[t]{3}{*}{30.88} \\
\hline $\mathrm{M}_{2}$ & 2.451 & $28 / 11 / 18$ & $24 / 12 / 18$ & 348.82 & 34.88 & \\
\hline$M_{3}$ & 2.701 & $28 / 11 / 18$ & $24 / 12 / 18$ & 333.21 & 33.32 & \\
\hline \multicolumn{7}{|c|}{28 DAYS } \\
\hline $\mathrm{M}_{1}$ & 2.456 & $28 / 11 / 18$ & $30 / 12 / 18$ & 370 & 37 & \multirow[t]{3}{*}{37.16} \\
\hline $\mathrm{M}_{2}$ & 2.457 & $28 / 11 / 18$ & $30 / 12 / 18$ & 390 & 39 & \\
\hline$M_{3}$ & 2.512 & $28 / 11 / 18$ & $30 / 12 / 18$ & 355 & 35.5 & \\
\hline
\end{tabular}

\subsection{COMPRESSIVE STRENGTH FOR BASALT}

The result for the compressive strength for basalt as shown in Table 5 indicate a relatively higher valued compared to that of granite after 28 days of curing. The relationship between number of days and compressive strength for basalt; while comparison between the compressive strength of granite and bassalt after 28days is as presented on Table 5. This implies that, granite have a lesser compressive strength than basalt i.e the compressive strength of basalt is relatively higher than that of granite.

Table 5: Compressive Strength For Basalt

\begin{tabular}{|c|c|c|c|c|c|c|}
\hline \multicolumn{7}{|c|}{ Compressive Strength Tests (Basalt) } \\
\hline S/N & $\mathrm{M}(\mathrm{kg})$ & $\begin{array}{c}\text { Casting } \\
\text { Date }\end{array}$ & $\begin{array}{c}\text { Crushing } \\
\text { Date }\end{array}$ & $\begin{array}{c}\text { Crushing } \\
\text { Force }(\mathrm{kN})\end{array}$ & $\begin{array}{c}\text { Compressive Strength } \\
\left(\mathrm{N} / \mathrm{mm}^{2}\right)\end{array}$ & $\begin{array}{c}\text { Average strength } \\
\left(\mathrm{N} / \mathrm{mm}^{2}\right)\end{array}$ \\
\hline 3 DAYS & & & & & 19.74 & \multirow{2}{*}{23.2} \\
\cline { 1 - 4 } $\mathrm{M}_{1}$ & 2.466 & $28 / 11 / 18$ & $1 / 12 / 2018$ & 197.37 & 25.74 & \\
\hline $\mathrm{M}_{2}$ & 2.501 & $28 / 11 / 18$ & $1 / 12 / 2018$ & 257.38 & 24.12 & \\
\hline $\mathrm{M}_{3}$ & 2.51 & $28 / 11 / 18$ & $1 / 12 / 2018$ & 241.19 & & 24.89 \\
\hline 7DAYS & & & & & 23.96 & \\
\hline $\mathrm{M}_{1}$ & 2.592 & $28 / 11 / 18$ & $6 / 12 / 2018$ & 239.58 & 22.72 & \\
\hline $\mathrm{M}_{2}$ & 2.711 & $28 / 11 / 18$ & $6 / 12 / 2018$ & 227.24 & 28 & \\
\hline $\mathrm{M}_{3}$ & 2.581 & $28 / 11 / 18$ & $6 / 12 / 2018$ & 279.99 & & \\
\hline
\end{tabular}


Ubi S.E, Nkra P.O, Agbor R.B, Ewa D.E, and Nuchal M

\begin{tabular}{|c|c|c|c|c|c|c|}
\hline \multicolumn{7}{|c|}{14 DAYS } \\
\hline $\mathrm{M}_{1}$ & 2.6 & $28 / 11 / 18$ & $18 / 12 / 18$ & 219.85 & 21.99 & \multirow[t]{3}{*}{26.29} \\
\hline $\mathrm{M}_{2}$ & 2.65 & $28 / 11 / 18$ & $18 / 12 / 18$ & 324.6 & 32.46 & \\
\hline $\mathrm{M}_{3}$ & 2.6 & $28 / 11 / 18$ & $18 / 12 / 18$ & 244.29 & 24.43 & \\
\hline \multicolumn{7}{|c|}{21 DAYS } \\
\hline$M_{1}$ & 2.468 & $28 / 11 / 18$ & $24 / 12 / 18$ & 319.01 & 31.9 & \multirow[t]{3}{*}{31.83} \\
\hline $\mathrm{M}_{2}$ & 2.47 & $28 / 11 / 18$ & $24 / 12 / 18$ & 316.63 & 31.66 & \\
\hline $\mathrm{M}_{3}$ & 2.709 & $28 / 11 / 18$ & $24 / 12 / 18$ & 319.28 & 31.93 & \\
\hline \multicolumn{7}{|c|}{28 DAYS } \\
\hline $\mathrm{M}_{1}$ & 2.479 & $28 / 11 / 18$ & $30 / 12 / 18$ & 393.16 & 39.32 & \multirow[t]{3}{*}{36.39} \\
\hline $\mathrm{M}_{2}$ & 2.542 & $28 / 11 / 18$ & $30 / 12 / 18$ & 308.36 & 30.84 & \\
\hline $\mathrm{M}_{3}$ & 2.52 & $28 / 11 / 18$ & $30 / 12 / 18$ & 390 & 39 & \\
\hline
\end{tabular}

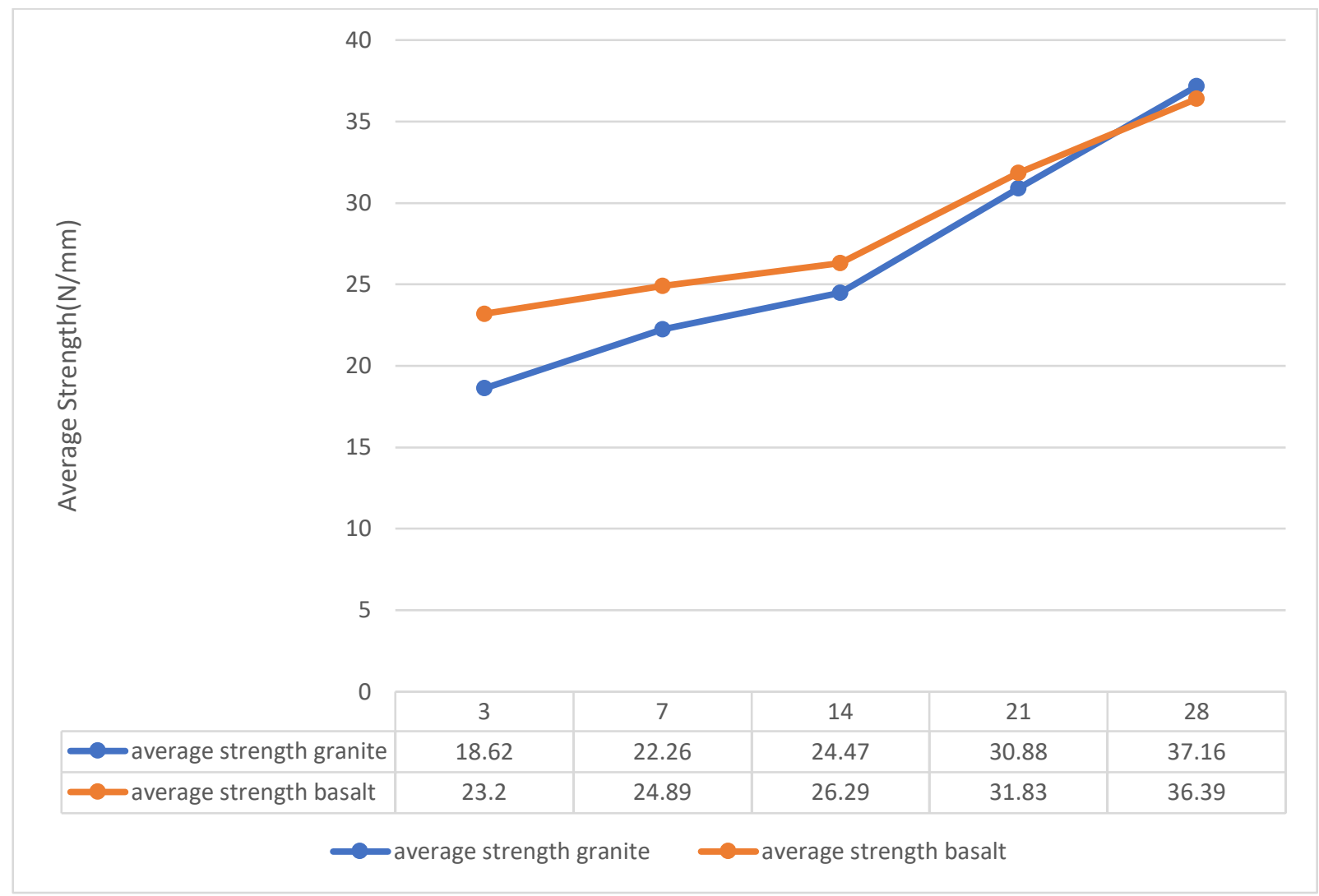

Figure 2: Compressive strength for granite and basalt

\subsection{SPLIT TENSILE STRENGTH TEST}

The cylinder split tensile strength result for granite in Table 7, shows the result for the cylinder split tensile stremngth test for granite after 28days. The result shows the average tensile strength was $12.57 \mathrm{~N} / \mathrm{mm}^{2}$. Split tensile strength base on days of crushing and applied force was calculated from

$$
T=\frac{2 P}{\pi L d}
$$

Where: $\mathrm{P}$ is the applied load, $\mathrm{L}$ is the length of cylinder say $300 \mathrm{~mm}$ and $\mathrm{d}$ is the diameter of cylinder say $150 \mathrm{~mm}$. 
Table 6: Cylinder Split Compressive Strength Test of Granite at 28 Days

\begin{tabular}{|c|c|c|c|c|c|c|}
\hline \multicolumn{3}{|c|}{ 28 DAYS } & \multicolumn{3}{c|}{ Cylinder Split Tensile Strength Tests (Granite) } \\
\hline $\mathrm{S} / \mathrm{N}$ & $\mathrm{M}(\mathrm{kg})$ & Casting Date & $\begin{array}{c}\text { Crushing } \\
\text { Date }\end{array}$ & $\begin{array}{c}\text { Applied Force } \\
(\mathrm{kN})\end{array}$ & $\begin{array}{c}\text { Split tensile Strength } \\
\left(\mathrm{N} / \mathrm{mm}^{2}\right)\end{array}$ & $\begin{array}{c}\text { Average strength } \\
\left(\mathrm{N} / \mathrm{mm}^{2}\right)\end{array}$ \\
\hline $\mathrm{M}_{1}$ & 14.7 & $12 / 12 / 2018$ & $18 / 12 / 18$ & 96.37 & 13.63 & 12.57 \\
\hline $\mathrm{M}_{2}$ & 13.2 & $12 / 12 / 2018$ & $18 / 12 / 18$ & 69.1 & 9.77 & \\
\hline $\mathrm{M}_{3}$ & 15 & $12 / 12 / 2018$ & $18 / 12 / 18$ & 101.16 & 14.3 & \\
\hline
\end{tabular}

\subsection{CYLINDER SPLIT TENSILE STRENGTH FOR BASALT}

The result for the cylinder split tensile strength test for basalt after 28days is shown on Table 8. The result shows the average tensile strength is $24.81 \mathrm{~N} / \mathrm{mm} 2$; while Fig. 2 also show the comparison of the cylinder split tensile strength test for basalt and granite. It showed that the tensile strength for granite lagged that of basalt by over 50 percent. The Table 8 also highlight the split tensile strength result with days weight of sample casting date crushing date, applied force and split tensile strength calculated from

$$
T=\frac{2 P}{\pi L d}
$$

Where: $\mathrm{P}$ is the applied load, $\mathrm{L}$ is the length of cylinder say $300 \mathrm{~mm}$ and $\mathrm{d}$ is the diameter of cylinder say $150 \mathrm{~mm}$.

Table 7: Cylinder Split Tensile Strength For Basalt

\begin{tabular}{|c|c|c|c|c|c|c|}
\hline \multicolumn{7}{|c|}{28 Days Cylinder Split Tensile Strength Tests (Basalt) } \\
\hline $\mathrm{S} / \mathrm{N}$ & $\mathrm{M}(\mathrm{kg})$ & Casting Date & $\begin{array}{c}\text { Crushing } \\
\text { Date }\end{array}$ & $\begin{array}{c}\text { Applied Force } \\
(\mathrm{kN})\end{array}$ & $\begin{array}{c}\text { Split tensile Strength } \\
\left(\mathrm{N} / \mathrm{mm}^{2}\right)\end{array}$ & $\begin{array}{c}\text { Average strength } \\
\left(\mathrm{N} / \mathrm{mm}^{2}\right)\end{array}$ \\
\hline $\mathrm{M}_{1}$ & 14.7 & $12 / 12 / 2018$ & $18 / 12 / 18$ & 195.57 & 27.67 & 24.81 \\
\hline $\mathrm{M}_{2}$ & 13.2 & $12 / 12 / 2018$ & $18 / 12 / 18$ & 220.41 & 31.18 & \\
\hline $\mathrm{M}_{3}$ & 15 & $12 / 12 / 2018$ & $18 / 12 / 18$ & 110.21 & 15.59 & \\
\hline
\end{tabular}

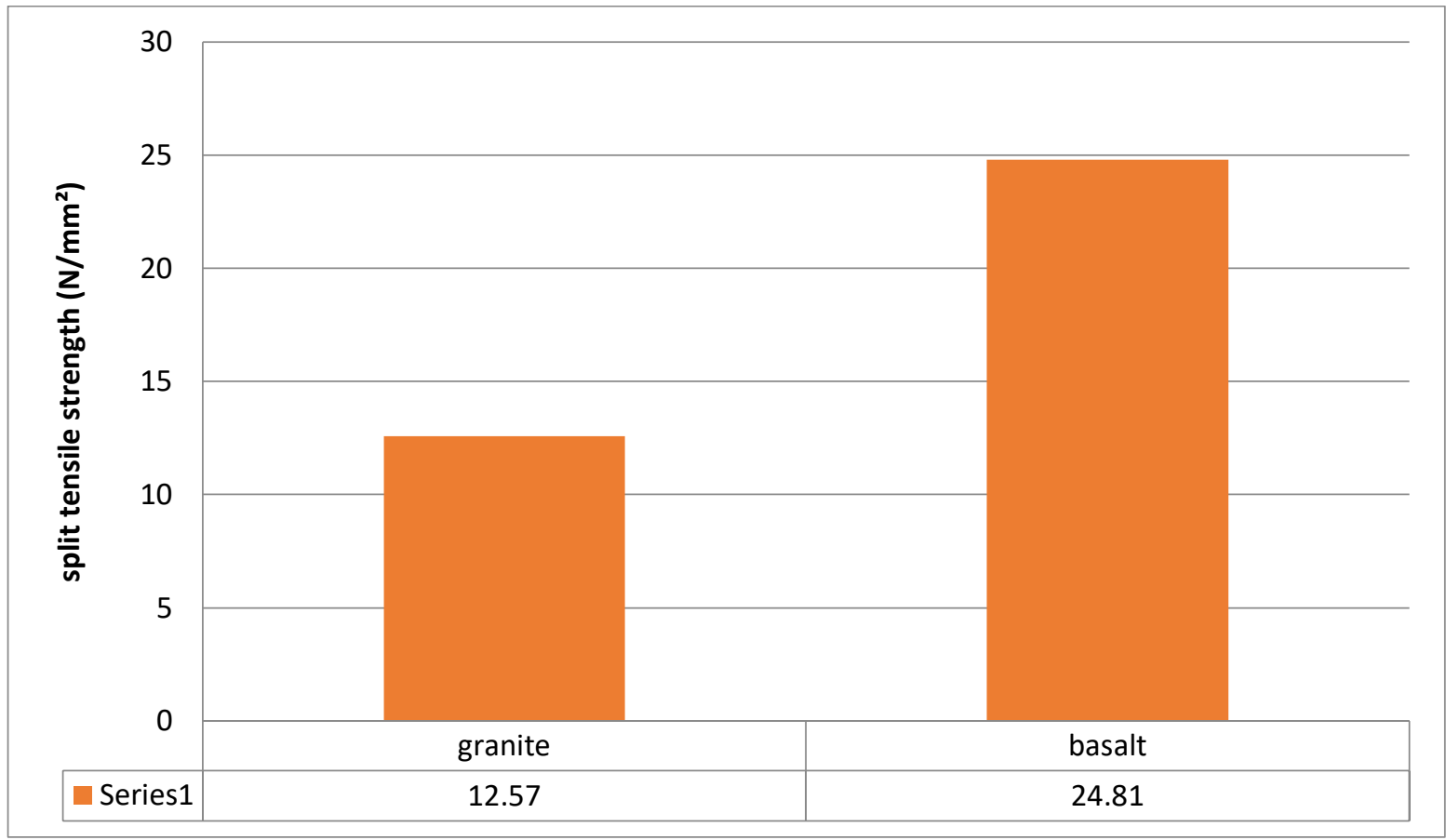

Figure 3: Comparison of granite to basalt 


\subsection{FLEXURAL STRENGTH TEST}

The beam strength of flexural after 28 days is $27.97 \mathrm{~N} / \mathrm{mm} 2$ for granite test and the test for basalt is $31.83 \mathrm{~N} / \mathrm{mm} 2$ respectively. The result for the Beam flexural strength test for granite after 28days is as shown in Table 8. Table 9 shows the result for the beam flexural strength test for basalt after 28days; while Fig. 3 is a comparison of the beam flexural strength test for basalt and granite. This showed that the beam flexural strength test for granite is lesser than that of bassalt, hence, flexural strength is calculated from

$$
F_{b}=\frac{3 P * L}{b * d}
$$

Where: $\mathrm{P}$ is the applied load, $\mathrm{L}$ is the length of sample say $300 \mathrm{~mm}, \mathrm{~b}$ is the breath of sample say $150 \mathrm{~mm}$ and $\mathrm{d}$ is the depth of sample say $150 \mathrm{~mm}$.

Table 8: Beam flexural strength test of granite at 28days

\begin{tabular}{|c|c|c|c|c|c|c|}
\hline \multicolumn{4}{|r|}{28 Days } & \multicolumn{3}{|c|}{ Beam Flexural Strength Tests (Granite) } \\
\hline $\mathrm{S} / \mathrm{N}$ & $\mathrm{M}(\mathrm{kg})$ & Casting Date & $\begin{array}{l}\text { Crushing } \\
\text { Date }\end{array}$ & $\begin{array}{c}\text { Applied } \\
\text { Force }(\mathrm{kN})\end{array}$ & $\begin{array}{c}\text { Flexural Strength } \\
\left(\mathrm{N} / \mathrm{mm}^{2}\right)\end{array}$ & $\begin{array}{c}\text { Average strength } \\
\left(\mathrm{N} / \mathrm{mm}^{2}\right)\end{array}$ \\
\hline $\mathrm{M}_{1}$ & 16.93 & $12 / 12 / 2018$ & $18 / 12 / 18$ & 68.16 & 27.26 & 27.97 \\
\hline $\mathrm{M}_{2}$ & 17.64 & $12 / 12 / 2018$ & $18 / 12 / 18$ & 49.63 & 19.85 & \\
\hline $\mathrm{M}_{3}$ & 16.94 & $12 / 12 / 2018$ & $18 / 12 / 18$ & 91.99 & 36.79 & \\
\hline
\end{tabular}

Table 9: Beam flexural strength test (basalt)

\begin{tabular}{|c|c|c|c|c|c|c|}
\hline \multicolumn{9}{|c|}{28 Days } & \multicolumn{2}{c|}{ Beam Flexural Strength Tests (Basalt) } \\
\hline $\mathrm{S} / \mathrm{N}$ & $\mathrm{M}(\mathrm{kg})$ & Casting Date & $\begin{array}{c}\text { Crushing } \\
\text { Date }\end{array}$ & $\begin{array}{c}\text { Applied } \\
\text { Force }(\mathrm{kN})\end{array}$ & $\begin{array}{c}\text { Flexural Strength } \\
\left(\mathrm{N} / \mathrm{mm}^{2}\right)\end{array}$ & $\begin{array}{c}\text { Average strength } \\
\left(\mathrm{N} / \mathrm{mm}^{2}\right)\end{array}$ \\
\hline $\mathrm{M}_{1}$ & 16.93 & $12 / 12 / 2018$ & $18 / 12 / 18$ & 60.86 & 24.34 & 31.83 \\
\hline $\mathrm{M}_{2}$ & 17.64 & $12 / 12 / 2018$ & $18 / 12 / 18$ & 82.15 & 32.86 & \\
\hline $\mathrm{M}_{3}$ & 16.94 & $12 / 12 / 2018$ & $18 / 12 / 18$ & 95.7 & 38.28 & \\
\hline
\end{tabular}

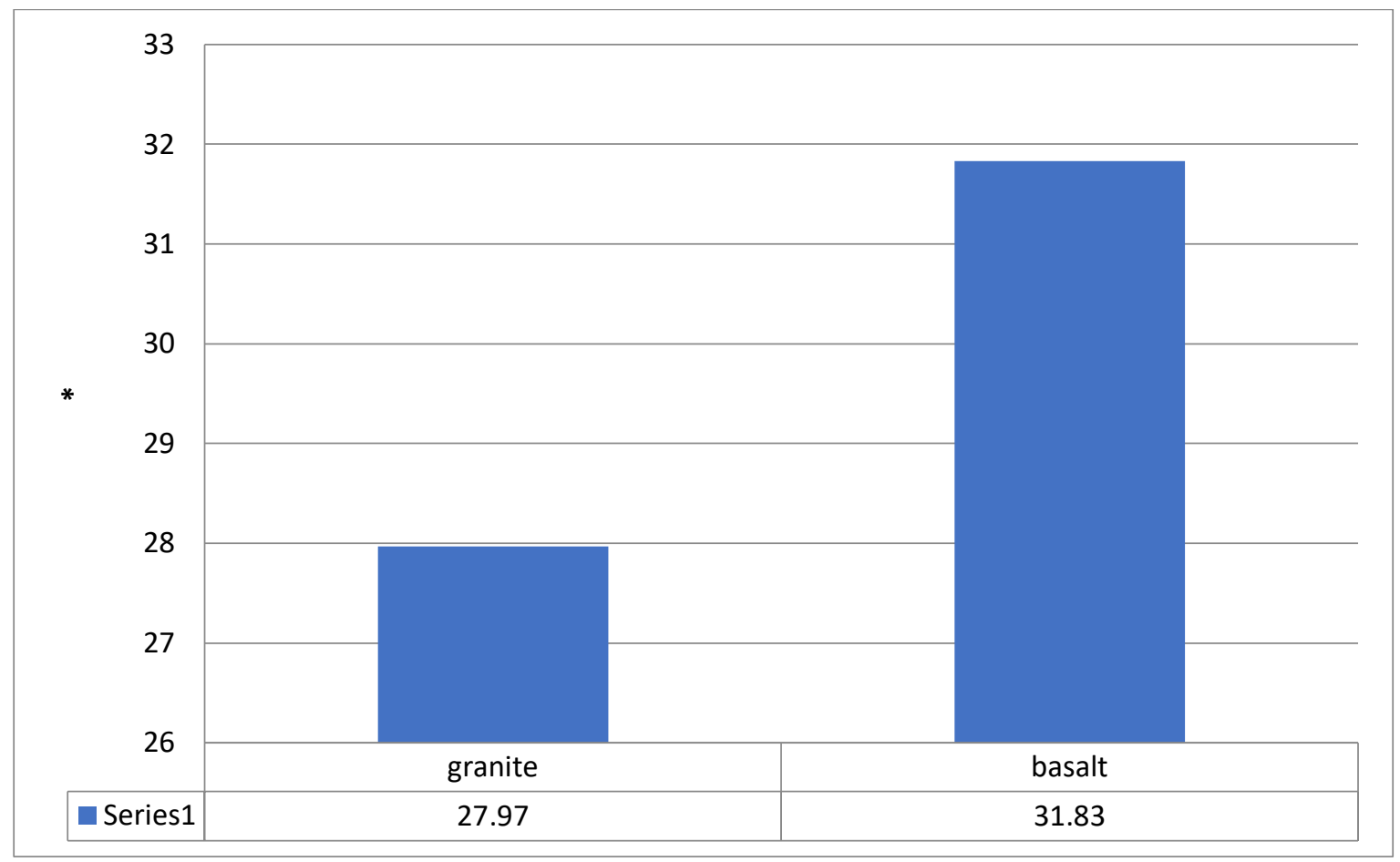

Figure 4: Flexural strength comparison of granite to basalt 


\section{CONCLUSION}

It was concluded from the test results that compressive strength increases the basalt percentage and enhances the mix strength over the conventional granite mix. This is due to the fact that basalt is denser and more durable and less water absorbing than granite. Also higher workability is obtained for more basalt aggregate content mix which reduces the cost of labour.

\section{SOURCES OF FUNDING}

None.

\section{CONFLICT OF INTEREST}

None.

\section{ACKNOWLEDGMENT}

None.

\section{REFERENCES}

[1] Dobiszewska M., Pichor W and Szoldra P. (2019): Effect of Basalt powder addition on properties of mortar. MATEC WEB of Conference, 262.

[2] Kasim M., Soram M., Dia E.N and Safia M.O (2017). Effect of aggregate properties on the mechanical and absoption characteristics of geopolymer mortar. Engineering science and Technology, an international Journal, 20(16):1642-1652.

[3] Kumar Y.Y., Vardhan C.M.V and Anitha A. (2015). Use of granite waste as partial substitute to cement in concrete. International Journal of Engineering Research and Application 5(4):25-31

[4] Krzysztof O., Lukasz S., Damian S., Daniel W., Tomasz G., Konrad O and Ireneusz U. (2018). Effect of the morphology of coarse aggregate on the properties of self-compacting high- performance Fibre-reinforced concrete. Material., 11(8): 1372

[5] Mehdi M., Payam S and Muhammad A (2018). The optimum oil palm shell content as coarse aggregate in concrete based on mechanical and durability properties. Advances in Material Sciences and Engineering.

[6] IS: 456 - 2000 (Fourth Revision) Indian Standard Plain and Reinforced Concrete Code of Practice.

[7] IS: 10262-2009 (first revision), Concrete Mix Proportioning Guidelines.

[8] IS: 383-1970 (Second Revision), Specifications for Coarse and Fine Aggregates from Natural Resources for Concrete.

[9] Ramakanta S., Byung J.S., Ji S.I. and Chul W.L (2012). A review of recent advances in catalytic hydrocracking of heavy residues. Journal of Industrial and Engineering Chemistry, 27: 12-24

[10] Sobera G. and Jose V., Relationship between gas adsorption and the shrinkage and creep of recycled aggregate concrete, Cement, Concrete \& Aggregates 25 (2) (2003). 